Journal of Applied Pharmaceutical Science Vol. 5 (10), pp. 052-058, October, 2015

Available online at http://www.japsonline.com

DOI: $10.7324 / \mathrm{JAPS} .2015 .501010$

ISSN 2231-3354 (cc) BY-NC-SA

\title{
Antimicrobial activities of Balanites aegyptiaca (L.) Delile (Balanitaceae) on bacteria isolated from water well
}

\author{
Kokou Anani ${ }^{1,3,4^{*}}$, Yao Adjrah ${ }^{1,3,4}$, Yaovi Améyapoh ${ }^{1,3}$, Simplice Damintoti Karou ${ }^{1,3,4}$, Amegnona Agbonon ${ }^{2,3}$, \\ Comlan de Souza ${ }^{1,3}$, Messanvi Gbeassor ${ }^{2,3}$ \\ ${ }^{1}$ Laboratoire de Microbiologie et de Contrôle de Qualité des Denrées Alimentaires, Ecole Supérieure des Techniques Biologiques et Alimentaires - \\ (ESTBA)- Université de Lomé, B.P. 1515, Lomé - Togo. \\ ${ }^{2}$ Laboratoire de Physiologie et de Pharmacologie, Faculté des Sciences - Université de Lomé, BP. 1515, Lomé - Togo. \\ ${ }^{3}$ Centre de Recherche et de Formation sur les Plantes Médicinales (CERFOPLAM), Université de Lomé, Togo. \\ ${ }^{4}$ Centre de Recherche en Agriculture Biologique et Substances Naturelles (CRABISNA), Lomé - Togo.
}

\author{
ARTICLE INFO \\ Article history: \\ Received on: 11/02/2015 \\ Revised on: 23/03/2015 \\ Accepted on: 16/04/2015 \\ Available online: 28/10/2015 \\ Key words: \\ Balanites aegyptiaca, \\ Phytochemicals, Well water, \\ Antimicrobial.
}

\begin{abstract}
Bark of Balanites aegyptiaca is used to make well water potable. This study aimed to investigate well water microbiological quality and appreciate antibacterial activity of crude extracts of B. aegyptiaca on bacteria isolated from 60 samples well water. Qualitative chemical analysis of the extract was carried out. Microbiological quality of water well from four health Districts of the city of Lomé were evaluated by broth dilution associated with the spread on agar media method. Antimicrobial activity of bark of B. aegyptiaca was assessed using microdilution method. The results indicated that well water samples analysed were contaminated to varying degrees by the total aerobic flora, fecal coliforms and fecal enterococci. The most important phytoconstituents of the back were saponins, coumarins, triterpenes, tannins and steroids. Flavonoids and polyphenols were absent. $B$. aegyptiaca inhibited significantly the growth of microorganisms isolated from well water. Using B. aegyptiaca in the disinfection of well water would be linked to its action on the causative organisms and its chemical composition.
\end{abstract}

\section{INTRODUCTION}

The access to safe and clean drinking water is a major concern throughout the world (Eze and Ananso, 2014). In many countries of Africa, water has become a scarce commodity as only a small proportion of the populace has access to treated water (Nkansah and Boadi, 2010). Over one third of the population still remains without access to safe water and sanitation and many of these can only be served by groundwater supplied by wells (Lawrence et al., 2001).

Unfortunately, contaminants such as bacteria, viruses, protozoan parasites render this type of water unsafe for human consumption as their presence indicates poor water quality and can lead to the widespread of water-borne diseases (Burch and Thomas, 1998). The most important waterborne diseases are typhoid, cholera, dysentery, enteritis, polio, infectious hepatitis, schistosomiasis and filariasis (Somani et al., 2011). Water may require treatment before drinking. The disinfection methods used

\footnotetext{
* Corresponding Author

Kokou Anani. E-mail: kokouanani@gmail.com
}

conventionally include pasteurization, chlorination, filtration, UV and ozonation (Canada et al., 2014; Burch and Thomas, 1998). The difficulty for adoption of conventional water treatment technologies in developing countries is as a result of the high cost and scarcity of chemical coagulants and disinfectants. The lack electricity in most communities in Sub-Saharan Africa makes it difficult to have water treatment technology that depends on electricity (Eze and Ananso, 2014). In addition, most of the chemical disinfectants used to ensure safe drinking water are associated with harmful effects on humans such as hemolytic anemia cancer risk, nervous system effect and liver effects (Canada et al., 2014; Rajendran et al., 2013). To meet these challenges, traditional water-purifying methods using herbs and seeds constitute one of the alternative approaches. There is always a search for novel water purification methods for domestic use. Traditionally, water is purified either by adding few herbals like Vetiveria zizanioides, Elettaria cardamom, Ocimum sanctum, Strychnos potatorum, Moringa oleifera (Eze and Ananso; Sathish, and Amuthan. 2012; Wadhwa et al., 2013). The bark of B. aegyptiaca is also used in rural milieu to purify freshwater, and 
every part of the plant is said to have beneficial properties. It is used as abortifacient and an antidote for arrow-poison in West African traditional (Cowan, 1999; Yadav and Panghal, 2010). Many parts of the plant are used as famine foods in Africa; the leaves raw or cooked, the oily seed mixed with sorghum used to prepare meals (Elfeed and Warrag, 2010; Wadhwa et al., 2013).

The bark, fruits, seeds, seed oil, root and leaves are widely used for the treatment of malaria, wound, jaundice, intestinal worm infection, syphilis, epilepsy, skin disease and dysentery. It also provides food, medicines, cosmetics, fodder, and pesticides valued for subsistence living in the rid and semi-arid areas where other options are few (Daya and Vaghasiya, 2011; Fawell and Nieuwenhuijsen, 2003). The purpose of this study is to evaluate the main chemical groups from the bark of $B$. aegyptiaca and to assess its antibacterial properties on fecal coliforms, Escherichia coli, fecal enterococci and total aerobic flora isolated from well water.

\section{MATERIALS AND METHODS}

\section{Plant material and extracts}

Bark of B. aegyptiaca was harvested in February 2014 at Aného, a town on Atlantic Ocean coast in south of Togo. It has been authenticated at "Département de Physiologie Végétale de la Faculté des Sciences de Université de Lomé" in Togo. The voucher specimen number is Togo 09439. Bark sample was dried at room temperature during 96 hours. It was pulverized and then subjected to percolation with ethanol-water $(70: 30, \mathrm{~V} / \mathrm{V})$ for 48 hours. The solution was decanted and then filtered through Whatman filter paper \# 1 and evaporated to dryness using an evaporator type Buchi. Dry extract was then frozen and lyophilized.

\section{Well water samples and germs isolation}

Well water samples $(\mathrm{n}=60)$ collected in $500 \mathrm{~mL}$ sterile flasks tied with a string to a piece of about $500 \mathrm{~g}$ of metal. The flask cap was aseptically removed and the weighted flask lowered into the well about 1 meter of depth (Idowu et al., 2011). Collection of samples was done in four health Districts coded D1, D2, D3 and D4 of the city of Lomé. Samples were brought to the laboratory in coolers equipped with icepacks and analysis began an hour later. Microbiological criteria of the "Association Française de Normalisation (AFNOR)"(NF EN ISO 6222) and of the World Health Organization on the quality of ground water were used. WHO guidelines recommend absence of Escherichia coli and fecal coliforms in $100 \mathrm{~mL}$ of water sample (WHO, 2008). According to the European Union criteria, the parameters were as follows: total aerobic flora $(<100 / \mathrm{mL})$, fecal coliforms $(0 / \mathrm{mL})$, Escherichia coli $(0 / \mathrm{ml})$ and fecal enterococci $(0 / \mathrm{mL})$. Broth dilution method followed by plating on agar was used. Media were inoculated with different dilutions of each water sample and incubated at $44{ }^{\circ} \mathrm{C}$ for 24 hours and $30{ }^{\circ} \mathrm{C}$ for 72 hours respectively to enumerate fecal coliforms, Escherichia coli on Violet Red Bile Agar and total aerobic flora on Plate Count Agar.
Slanetz Bartley was used for fecal enterococci at $37^{\circ} \mathrm{C}$ for 48 hours.

\section{Chemical and biochemical}

All media for microbial growth: Plate Count Agar, Violet Red Bile Agar, Slanetz and Bartley, Mueller Hinton, nutrient agar and trypton salt were from Bio-Rad (France), Dragendorff reagent and 2, 2-diphenyl-1picrylhydrazyl (DPPH) were obtained from Sigma Chemical Company (Saint Louis, USA). The other chemicals were of analytical grade.

\section{Phytochemical screening}

Qualitative chemical analysis of the extract was carried out to determine the content of tannins, alkaloids, and saponins by foam test, coumarins $\left(\mathrm{NH}_{4} \mathrm{OH}\right)$, and flavonoids by Shibata reaction, steroids and terpenes ( Khan et al., 2011). The results were expressed as relative abundance.

\section{Tannins}

Dry extracts $(10 \mathrm{mg})$ were dissolved in $2 \mathrm{~mL}$ of distilled water. The solution was supplemented with3 drops of $\mathrm{FeCl}_{3}$. The apparition of a blue-black color or a green-black color indicates the presence of tannins.

\section{Flavonoids}

A mixture of $10 \mathrm{mg}$ of extract in $2 \mathrm{~mL}$ of $50 \%$ hot methanol was prepared. The solution was supplemented with $5 \mathrm{~mL}$ of magnesium turnings followed by a few drops of concentrated chloridrique acid. The appearance of a red color indicates the presence of flavonoids.

\section{Alkaloids}

Ten milligrams of dry extracts were dissolved in $1.5 \mathrm{~mL}$ chloridrique acid $2 \%$. The resulting solution was divided into three clean and dry tubes. The first tube served as a control. In the two remaining tubes, 2-3 drops of Dragendorff reagent and Bertrand were added respectively. Alkaloids were indicated by appearance of precipitates.

\section{Triterpens and steroids}

To determine these compounds, $10 \mathrm{mg}$ of the dry extract were dissolved in $0.5 \mathrm{~mL}$ of aceticanhydride. The solution was supplemented with $0.5 \mathrm{~mL}$ of chloroform and divided in two dry tubes. One of the tubes served as control. In the second tube, 1-2 $\mathrm{mL}$ of $\mathrm{H}_{2} \mathrm{SO}_{4}$ were gently added. A reddish brown ring appeared at the interface while the upper phase was colored green or purple according to the extract concentration. The presence of this ring coupled to the green or purplish coloration of the upper phase indicates the presence of triterpenes and steroids. Color contrast depends on the concentration of the triterpens and steroids.

\section{Coumarins}

Ten milligrams of dry extract were dissolved in hot distilled water. After cooling, the solution was divided into two 
tubes. The first served as control. In the second one, $0.5 \mathrm{~mL}$ of $10 \% \mathrm{NaOH}$ was added. The appearance of a fluorescent under ultraviolet illumination indicates the presence of coumarins.

Saponins

A mixture of $10 \mathrm{mg}$ of dry extract and $3 \mathrm{~mL}$ of distilled water was shaken for 30 seconds. The stable foam appearance indicates the presence of saponins. The size of the foam is proportional to the concentration of saponins.

\section{Determination of minimum inhibitory concentration (MIC) and minimum bactericidal concentration (MBC)}

Antimicrobial activities tests were performed in triplicate using broth microdilution method according to published protocols in 96-wells plate (NCCLS, 2002) to determine the MICs. Tested concentrations of extracts range from 4000 to $2.5 \mu \mathrm{g} / \mathrm{mL}$ in distilled water. Isolated bacteria strains from water wells samples were cultured on nutrient agar for 24 hours. Colonies were suspended in distilled water to a turbidity of 0.5 Mac Farland standards $\left(10^{8} \mathrm{cfu} / \mathrm{mL}\right)$. The suspension was diluted 1:1000 in Müller Hinton broth to obtain around $10^{4} \mathrm{cfu}$ per well. Negative control wells consist of extracts and medium while positive ones were made of medium and bacteria without extract. The lowest concentration that completely inhibited visible growth was recorded as the MIC. Subcultures were made from clear wells which did not show any growth on nutrient agar to appreciate MBC. Lowest concentrations without growth after the subculturing were MBCs.

\section{Statistical analysis}

Values of germs counting was expressed as mean \pm SEM. Significant differences between Districts were determined with analysis of variance (ANOVA) using Systat 5.0 software. Pair wise comparisons were done using the Fisher LSD at $P<0.05$. Graphics were performed using Graphpad Prism version 5.00 (Graphpad Software, San Diego, USA).

\section{RESULTS AND DISCUSSION}

\section{Bacteria isolated from well water}

Water samples were collected in shallow wells from 4 to 11 meters. They were all contaminated with total bacteria flora, fecal enterococci, fecal coliforms and Escherichia coli in varying level. No well water sample was free of total aerobic flora. The count values of this flora range from 5 to $678 ; 17$ to $554 ; 5$ to 465 and from 2 to 827 per mL respectively for Districts $1 ; 2 ; 3$ and 4 (Table 1). Four wells (26.6\%) in District 1; two (13.33\%) in Districts 2 and 4 did not contain fecal coliforms. Only one well of the District 3 was contaminated with fecal coliforms (Table 2). Regarding Escherichia coli, $26.6 \%$ well water samples in District $1 ; 20 \%$ in Districts 2 and 4 were contaminated. E. coli was counted in one well in District 3 (Table 3). Fecal enterococci were counted in $80 \% ; 73 \% ; 53 \%$ and $33 \%$ of water samples from wells tested respectively in Districts 3; 4; 1 and 2 (Table 4). According to AFNOR criteria, the results revealed that $8(53.33 \%) ; 9(60 \%) ; 7$
(46.66\%) and $6(40 \%)$ water well samples were conform relative to total aerobic flora respectively in Districts $1 ; 2 ; 3$ and 4 . In the case of fecal coliforms, the compliance percentages were $26 \%$; $13.33 \%$; $6 \%$ and $13.33 \%$ from District 1 to 4 . Concerning Escherichia coli, the percentages were $26 \%$ for District $1 ; 20 \%$ for District 2; $13.33 \%$ for District 4 and 6.6\% for District 3. Isolation of $E$. coli and fecal coliforms bacteria indicate that water samples were contaminated by the feces of humans or animals. This observed fecal contamination is an indicator of potential risk to users of this water. Their presence may indicate recent contamination of the groundwater by human sewage or animal droppings which could contain other bacteria or viruses. The origins of these contaminations could be domestic sewage, human and animal waste, septic system too close to well, water well depth, activities (farming, mining industry) near the well, flooded wells and local aquifer heterogeneity (Fawell and Nieuwenhuijsen, 2003; Karwautz and Lueders, 2014). Therefore, coliforms bacteria in water well show that bacteria are continuously in contact with water or aquifer where water is withdrawn. Total bacteria flora, total coliform and fecal enterococci were found to be highest in domestic sewage and soil compared to industrial wastewater (Fawell and Nieuwenhuijsen, 2003; Malik and Ahmad, 2002). Escherichia coli grow in the intestinal tract of all animals (Frenzen et al., 2005).

There are pathogenic strains responsible for digestive disorders and systemic diseases. Among them, Escherichia coli O157H7 is found in animal feces, meat, raw milk and water recreation (Frenzen et al., 2005). This bacterium is responsible of diarrhea accompanied by abdominal pain and cramps; nausea and vomiting, thrombotic thrombocytopenic purpura and hemolytic uremic syndrome (Frenzen et al., 2005). Annual cost of illness due to $E$. coli from all sources of infection was $\$ 405$ million, including $\$ 370$ million for premature deaths, $\$ 30$ million for medical care and $\$ 5$ million for lost productivity (Cassin et al., 1998).

\section{Phytochemicals and antimicrobial activities}

Hydroethanolic extracts from the bark of B. aegyptiaca contains high levels of saponins, coumarins, triterpenes, tannins and steroids. Low amounts of alkaloids were recorded. Flavonoids and polyphenols are absent.

The entire total aerobic flora isolated in the four health Districts of the city of Lomé is inhibited to varying levels by the extract. No resistance observed. However, the MICs vary from each District to another. MIC is $100 \mu \mathrm{g} / \mathrm{mL}$ for 5 strains of total aerobic flora in District 1; 4 strains in District 3 and 3 strains in District 4. Two strains in District 1; 4 strains in Districts 2 and 3 and five strains in District 4 had the same MIC $(200 \mu \mathrm{g} / \mathrm{mL})$. Only 2 strains in District 1 had MIC equal to $500 \mu \mathrm{g} / \mathrm{mL}$ (Fig. 1). As total aerobic flora, all the 15 strains of fecal coliforms isolated from well water were inhibited with the extract. Values of MICs range from 100 to $800 \mu \mathrm{g} / \mathrm{mL}$ for District 1; 100 to $600 \mu \mathrm{g} / \mathrm{mL}$ for District 2; 100 to $500 \mu \mathrm{g} / \mathrm{mL}$ for District 3 and 100 to $400 \mu \mathrm{g} / \mathrm{mL}$ for District 4 (Fig. 2). About Escherichia coli, $200 \mu \mathrm{g} / \mathrm{mL}$ was the lowest MIC. The highest MICs values observed were $400 \mu \mathrm{g} / \mathrm{mL}$ 
and $450 \mu \mathrm{g} / \mathrm{mL}$ in Districts 1 and 4, respectively. Highest MIC for the two remaining Districts was $500 \mu \mathrm{g} / \mathrm{mL}$ (Fig. 3). Fecal enterococci strains isolated from well water in the four Districts are all sensitive to the extract. MICs obtained range from 100 to $200 \mu \mathrm{g} / \mathrm{mL}$ for Districts 1; 3 and 4. These values were 100 and 150 $\mu \mathrm{g} / \mathrm{mL}$ for District 2 (Fig. 4). Antibacterial effect exerted by $B$. aegyptiaca is linked to its secondary metabolites. There is a linear relation with the saponins content and antimicrobial activity (Khan et al., 2011). The major antimicrobial compounds from plants are terpenoids, phenolics, alkaloids, lectins, polypeptides and polyacetylenes (Cowan, 1999). Saponins in plants feature antimicrobial properties (Cassin et al., 1998). Saponins, triterpenoids, tannins, flavonoids and phenols are responsible for anti-inflammatory, antipasmodic, analgesic and diuretic activities (Abdallah, 2011). It has in addition to these activities, antimicrobial properties (Kalimuthu, 2014). Saponins reduce blood pressure and cholesterol level in blood and prevent artherosclerosis. It binds to cholesterol to constitute an insoluble complex excreted by bile (Soetan, 2008). Saponins are also equipped withanti-cancer and Hypolipidemic properties (Soetan, 2008).
Tannins are widely distributed in plants as secondary metabolites. Tannins are used to heal wounds internally, burn and stop bleeding and anti-inflammatory effects (Ashok and Upadhyaya, 2012). Tannins are important to be potent astringents to cure wounds and used as anti-inflammatory, antioxidant and antimicrobial compounds (Wagner, 1989). The ability of tannins to form a protective layer over the affected tissue keeps wound from another infection. In addition to these chemical compounds, bark contains calcium, iron, phosphorus, sulfur, potassium and manganese were found in stem bark (Gupta et al., 2012). The stem bark contains only flavonoids and polyphenols while the other phytochemicals are found in the others parts of the plant (Tula et al., 2014). Triterpenes, steroïds, sesquiterpens and polysaccharides exert their antiphlogistic activity by intervening in immunological reaction mechanisms (Wagner, 1989). No flavonoids in the extract. Antiinflammatory activity of triterpenes had been attributed respectively to inhibition of lipoxygenase and cyclooxygenase activities, inhibition of elastase and inhibition of complement.

Table 1: Distribution of total aerobic flora isolated in Districts.

\begin{tabular}{cccc}
\hline District 1 & District 2 & District 3 & District 4 \\
\hline $142 \pm 16.37$ & $168 \pm 11.13$ & $81 \pm 9.64$ & $6.33 \pm 2.88$ \\
$46.33 \pm 5.85$ & $56.33 \pm 5.85$ & $148 \pm 21.37$ & $2 \pm 3.46$ \\
$395.33 \pm 195.14$ & $26 \pm 3.46$ & $465.33 \pm 24.11$ & $118 \pm 3.05$ \\
$346 \pm 38.31$ & $215 \pm 16.09$ & $276.66 \pm 15.27$ & $221.66 \pm 20.20$ \\
$320.12 \pm 17.38$ & $168.33 \pm 17.38$ & $259 \pm 27.62$ & $401 \pm 13.52$ \\
$53 \pm 4.58$ & $17.33 \pm 3.05$ & $163.66 \pm 21.36$ & $89.66 \pm 7.37$ \\
$15 \pm 5$ & $54.33 \pm 6.02$ & $51.66 \pm 6.50$ & $48.33 \pm 4.04$ \\
$80.04 \pm 10.14$ & $71.66 \pm 4.72$ & $65 \pm 5.56$ & $45 \pm 13.74$ \\
$24.43 \pm 5.29$ & $12.66 \pm 2.08$ & $5.33 \pm 5.50$ & $322.66 \pm 16.62$ \\
$70.87 \pm 8.62$ & $53.33 \pm 6.11$ & $85.33 \pm 14.18$ & $268 \pm 19.07$ \\
$9.66 \pm 2.08$ & $28 \pm 4.58$ & $27.33 \pm 8.02$ & $100.66 \pm 12.09$ \\
$350.84 \pm 20.52$ & $158.66 \pm 27.97$ & $99.33 \pm 11.67$ & $62.33 \pm 8.08$ \\
$687.33 \pm 23.69$ & $554.66 \pm 34.07$ & $231.66 \pm 31.81$ & $583 \pm 26.51$ \\
$158.42 \pm 22.27$ & $117.33 \pm 9.29$ & $248 \pm 34.69$ & $827.33 \pm 29.68$ \\
\hline
\end{tabular}

Values indicate the mean of three observations of the number total aerobic flora counted per mL followed by standard deviation. The lowest and the highest values of total aerobic flora counted was observed in District $4(2 \pm 3.46$ and $827.33 \pm 29.68)$. Values observed $>200$ germs $/ \mathrm{mL}$ for $46.6 \%$ in District 4 ; $33.3 \%$ in Districts 1 and 3 and 13.3\% in District 2. Significant difference between District 1 and District 2,P<0.05. No significant difference between other Districts.

Table 2: Distribution of Fecal coliforms isolated in Districts.

\begin{tabular}{|c|c|c|c|}
\hline District 1 & District 2 & District 3 & District 4 \\
\hline $98.33 \pm 9.50$ & $69.33 \pm 4.16$ & $68.33 \pm 9.50$ & 0 \\
\hline 0 & $9.33 \pm 3.05$ & $91.33 \pm 3.05$ & 0 \\
\hline $102.66 \pm 14.50$ & 0 & $278 \pm 9.53$ & $56.33 \pm 9.07$ \\
\hline $124 \pm 11.53$ & $109.66 \pm 10.78$ & $165 \pm 10.00$ & $96.33 \pm 7.37$ \\
\hline $22.66 \pm 5.03$ & $20.33 \pm 1.52$ & $124 \pm 17.08$ & $229.33 \pm 46.70$ \\
\hline 0 & 0 & $56.66 \pm 6.80$ & $39.33 \pm 3.05$ \\
\hline 0 & $10.33 \pm 1.52$ & $34.66 \pm 6.80$ & $10 \pm 1.73$ \\
\hline $2.66 \pm 2.51$ & $25.33 \pm 2.51$ & $37.33 \pm 6.80$ & $22.66 \pm 2.51$ \\
\hline $45.33 \pm 8.08$ & $14 \pm 5.56$ & 0 & $142.33 \pm 3.78$ \\
\hline $24 \pm 3.46$ & $28.66 \pm 4.04$ & $48.33 \pm 3.51$ & $127.66 \pm 6.80$ \\
\hline $13.66 \pm 2.08$ & $5.66 \pm 2.51$ & $13 \pm 2.64$ & $26 \pm 11.13$ \\
\hline 0 & $51.66 \pm 12.22$ & $48 \pm 3.60$ & $35.33 \pm 8.38$ \\
\hline $215.66 \pm 9.45$ & $312.33 \pm 12.66$ & $156 \pm 8.54$ & $319.66 \pm 9.50$ \\
\hline $352.33 \pm 28.58$ & $41 \pm 6.92$ & $60 \pm 7.93$ & $468 \pm 35.79$ \\
\hline $165 \pm 10.53$ & $16 \pm 1.00$ & $75 \pm 10.53$ & $181.66 \pm 10.96$ \\
\hline
\end{tabular}

Values indicate the mean of three observations of the number total aerobic flora counted per mL followed by standard deviation. No fecal coliform observed in $26.6 \%$ well water samples analysed in District $1 ; 13.3 \%$ in District 2 and 4. Only a well was contaminated by these bacteria in District 3 . The lowest value observed is $2.66 \pm 2.51$ (District 1) and the highest is $468 \pm 35.79$ in District 4 . No significant difference between Districts, $P>0.05$. 
Table 3: Distribution of Escherichia coli isolated in Districts.

\begin{tabular}{|c|c|c|c|}
\hline District 1 & District 2 & District 3 & District 4 \\
\hline $47 \pm 4.58$ & $42 \pm 6.24$ & $49.66 \pm 5.03$ & 0 \\
\hline 0 & $4.33 \pm 3.78$ & $51.50 \pm 3.51$ & 0 \\
\hline $64.33 \pm 5.68$ & 0 & $112.33 \pm 7.09$ & $21 \pm 3.00$ \\
\hline $82.33 \pm 6.02$ & $67.66 \pm 5.50$ & $104.33 \pm 4.16$ & $18.66 \pm 5.85$ \\
\hline $16.33 \pm 3.05$ & $10.33 \pm 3.51$ & $82.33 \pm 4.50$ & $169 \pm 26.90$ \\
\hline 0 & 0 & $37.66 \pm 4.16$ & 0 \\
\hline 0 & $4 \pm 1.00$ & $15 \pm 5.00$ & $4 \pm 3.60$ \\
\hline $1.66 \pm 1.52$ & $11.33 \pm 3.51$ & $2.66 \pm 4.61$ & $16 \pm 2.00$ \\
\hline $28 \pm 6.00$ & $3.66 \pm 1.52$ & 0 & $41 \pm 10.44$ \\
\hline $19.33 \pm 3.51$ & $18.66 \pm 3.51$ & $31.66 \pm 3.51$ & $37 \pm 6.24$ \\
\hline $10 \pm 1.73$ & 0 & $7.33 \pm 2.08$ & $23.66 \pm 8.32$ \\
\hline 0 & $28 \pm 3.60$ & $19.66 \pm 6.80$ & $8 \pm 7.21$ \\
\hline $144.33 \pm 12.66$ & $244 \pm 12.16$ & $103.33 \pm 23.18$ & $119 \pm 21.00$ \\
\hline $247.33 \pm 18.00$ & $25 \pm 3.00$ & $25 \pm 2.64$ & $179.66 \pm 21.59$ \\
\hline $114.33 \pm 12.01$ & $12.33 \pm 2.51$ & $41 \pm 5.56$ & $75.66 \pm 7.09$ \\
\hline
\end{tabular}

Values indicate the mean of three observations of the number total aerobic flora counted per $\mathrm{mL}$ followed by standard deviation. Escherichia coli as counted in 93\% of well water analysed in District 3.80\% in Districts 2 and 4 and 73\% in District 1. The two most contaminated wells were observed in District $1(247.33 \pm$ $18.00)$ and District $2(244 \pm 12.16)$. The lowest value were $1.66 \pm 1.52$ (District 1), $2.66 \pm 4.61$ (District 3) and $3.66 \pm 1.52$ (District 2). No significant difference between Districts, $P>0.05$.

Table 4: Distribution of fecal enterococci isolated in Districts.

\begin{tabular}{|c|c|c|c|}
\hline District 1 & District 2 & District 3 & District 4 \\
\hline $20.66 \pm 0$ & $7 \pm 1$ & $44.33 \pm 10.40$ & $34.66 \pm 7.02$ \\
\hline 0 & 0 & $66 \pm 25.05$ & $14.66 \pm 3.05$ \\
\hline $46 \pm 10.58$ & 0 & $96 \pm 11.13$ & $28.66 \pm 4.16$ \\
\hline $28.66 \pm 7.57$ & $4.66 \pm 4.16$ & $72.66 \pm 7.57$ & $58 \pm 6.00$ \\
\hline 0 & 0 & $111.33 \pm 9.45$ & $85.66 \pm 10.96$ \\
\hline 0 & 0 & 0 & 0 \\
\hline 0 & 0 & $5 \pm 1.00$ & 0 \\
\hline 0 & 0 & 0 & $6 \pm 2.00$ \\
\hline $6 \pm 2$ & 0 & 0 & $40.33 \pm 6.80$ \\
\hline $1.33 \pm 2.30$ & $10 \pm 2$ & $37.33 \pm 22.03$ & $26.66 \pm 4.61$ \\
\hline 0 & 0 & 0 & 0 \\
\hline 0 & $4 \pm 2$ & $37 \pm 18.52$ & 0 \\
\hline $89.33 \pm 12.05$ & $84.33 \pm 14.57$ & $82.33 \pm 76.51$ & $102.66 \pm 15.01$ \\
\hline $110 \pm 14$ & 0 & $25.33 \pm 32.80$ & $120.66 \pm 12.05$ \\
\hline $58.66 \pm 8.26$ & 0 & $43 \pm 8.88$ & $21.66 \pm 3.51$ \\
\hline
\end{tabular}

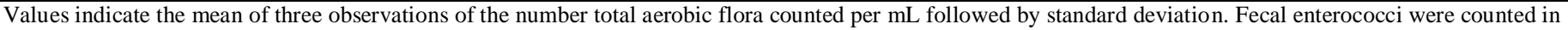
$73.33 \%$ well water samples analysed in Districts 3 and 4 . The lowest values were $5 \pm 1.00$ (District 3 ) and $6 \pm 2.00$. The lowest values were $1.33 \pm 2.30$ and $4 \pm 2$ and the highest $110 \pm 14$ and $84.33 \pm 14.57$ respectively in Districts 1 and $2.53 .3 \%$ well were contaminated by fecal enterococci in District 1 . No significant difference between Districts, $P>0.05$.

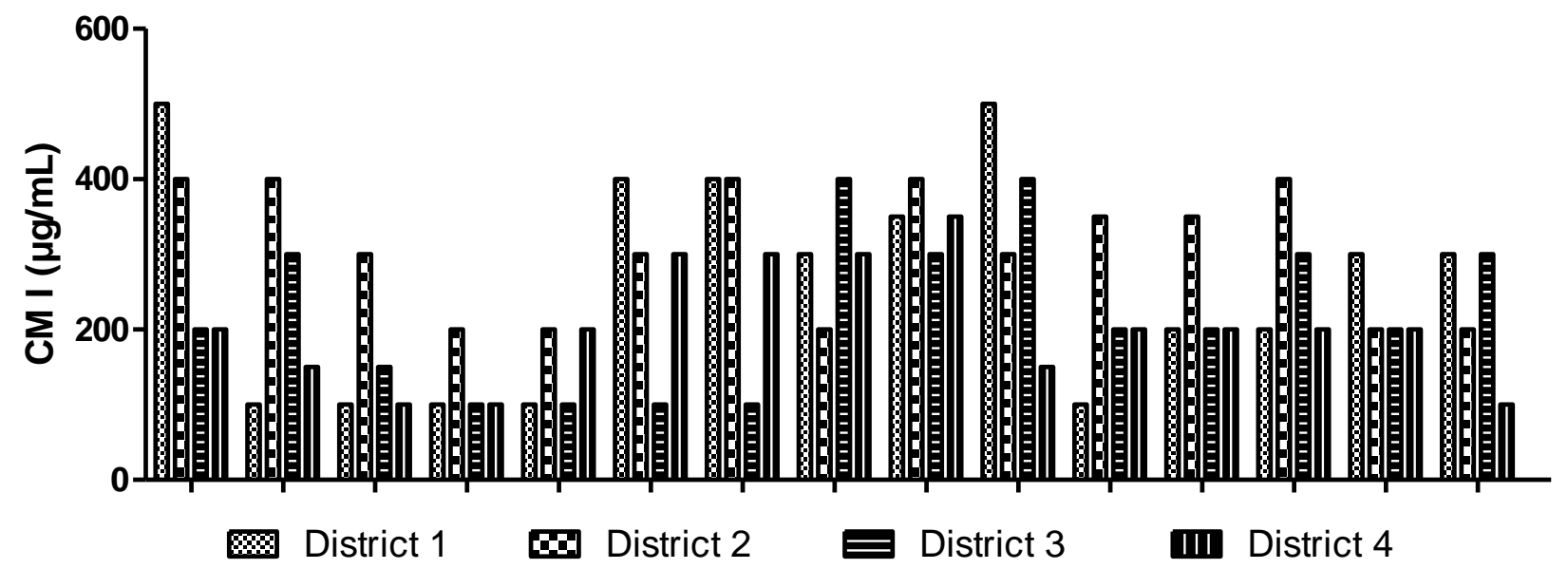

Fig. 1: Minimal inhibitory concentrations (MIC) of Balanites aegyptiaca on Total aerobic flora. Balanitesa egyptiaca extract was tested on15strains of total aerobic flora isolated from well water. Values observed indicate MICs ( $\mu \mathrm{g} / \mathrm{mL})$ of total aerobic flora. Lowest MIC values were 100 for Districts 1 ; 3 and 4 . It was 200 for District 2. In contrast the highest values were 350 for District 4, 400 for Districts 2 and 3 and 500 for District 1. Difference significant between Districts, $P<0.05$ 


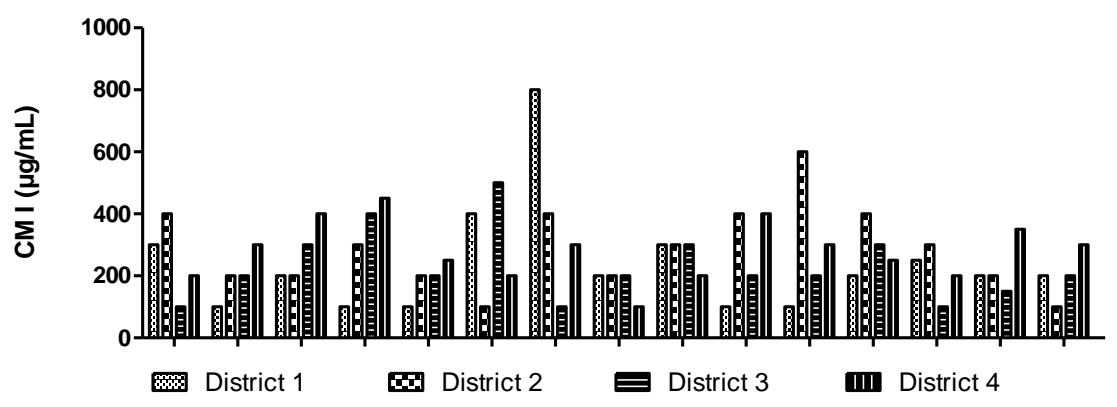

Fig.2: Minimal inhibitory concentrations (MIC) of Balanites aegyptiaca on fecal coliforms. Values indicate MICs ( $\mu \mathrm{g} / \mathrm{mL})$ of Balanites aegyptiaca on 15 strains of fecal coliforms isolated from well water. Lowest values were 100 and the highest values were $800 ; 600 ; 500$ and 450 respectively for District $1 ; 2 ; 3$ and 4 . Difference significative between Districts, $P<0.05$

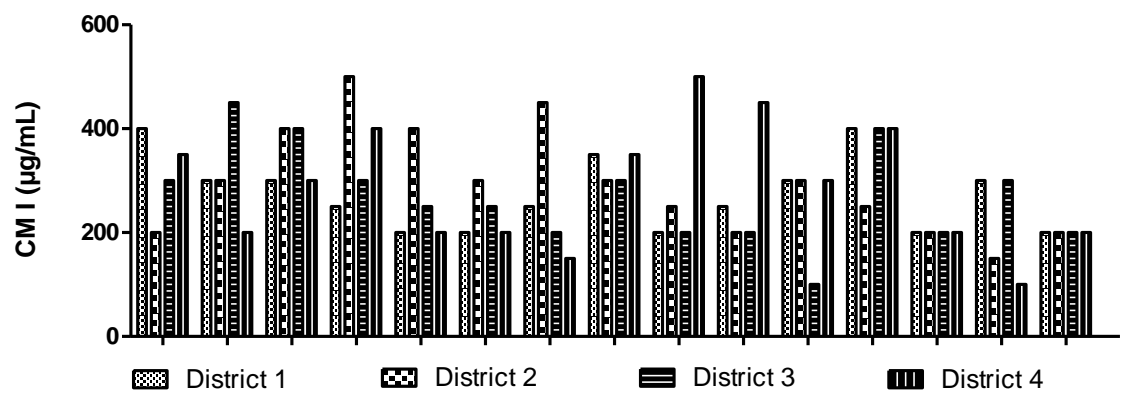

Fig.3: Minimal inhibitory concentrations (MIC) of Balanites aegyptiaca on Escherichia coli.

Values indicate MICs $(\mu \mathrm{g} / \mathrm{mL})$ of Balanites aegyptiaca on 15 strains of E. coli isolated from well water. MICs range from 100 to $500 \mu \mathrm{g} / \mathrm{mL}$. Highest values were 400; 500; 450 and 500 respectively for District 1;2; 3 and 4. Difference significative between Districts, $P<0.05$.

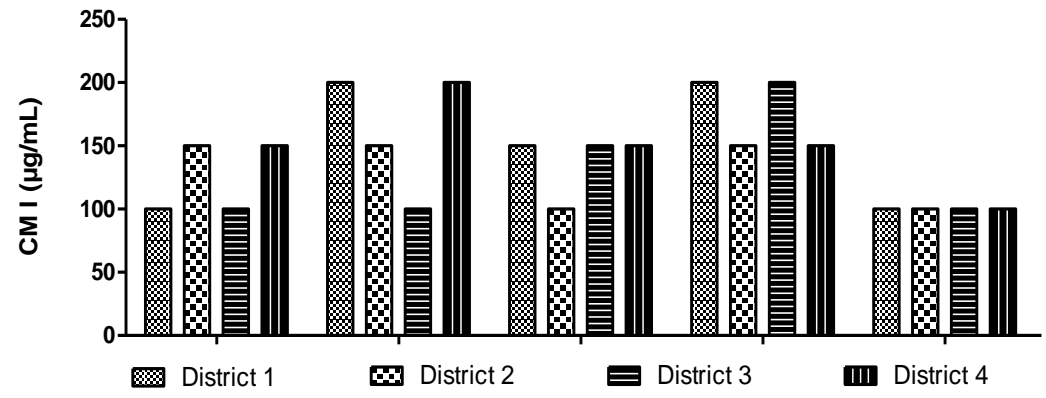

Fig. 4: Sensibility of Fecal enterococci to Balanites aegyptiaca. Values correspond MICs expressed in $\mu \mathrm{g} / \mathrm{mL}$. Twenty strains isolated from water well were tested. MICs range from 100 to 200 for Districts 1; 3 and 4. MICs are 100 and 150 for District 2. Lowest value was 100 and the highest was 200 in Districts 1; 3 and 4. No significant difference, $P>0.05$.

\section{CONCLUSION}

B. aegyptiaca contains high levels of saponins, coumarins, triterpenes, tannins and steroids. It inhibits in vitro growth of all bacteria isolated from Well water. Well water from Districts1, 2, 3 and 4 of Lomé in Togo (West Africa) are contaminated to varying level by the total aerobic flora, fecal coliforms and Escherichia coli. The use of B. aegyptiaca in the purification of well water would be partly related to its action on bacteria isolated.

\section{ACKNOWLEDGEMENTS}

Our sincerely gratitude to Mr. Dossèh Kossivi and Mr. Idoh Kokou for their skiful technical assistance.

\section{REFERENCE}

Abdallah E.M. Plants: An alternative source for antimicrobials. J. Applied. Sci. 2011;1: 16-20.

Ashok K.P., Upadhyaya K. Tannins astringent. J. Pharmacogn and Phytochem. 2012; 1: 45-50.

Burch J.D., Thomas K.E. Water disinfection for developing countries and potential for solar thermal pasteurization. Solar Energy. 1998;64: 87-97.

Canada M.L.M., Abelan S.U., Zangaro A.R., KozusnyAndreani I.D., Yamazaki C.F.R. Effectiveness of ozonated water in the reprocessing of blood dialyzers. Engenharia Biomedica. 2014; 30: 215 219.

Cassin H.M., Lammerding M.A., Todd CDE, Ross WR, McColl. Quantitative risk assessment for Escherichia coli $\mathrm{O} 157 \mathrm{H} 7$ in ground beef hamburgers. Int. J. Food Microbiol. 1998; 41:21-44.

Cowan M.M. Plant product as antimicrobial agents. Clin Microbiol Rev. 1999; 12: 564-582. 
Daya C.L., Vaghasiya H.U. A review on Balanites aegyptiaca Del (desert date): phytochemical constituents, traditional uses and pharmacological activity. Pharmacogn Rev.2011; 5: 55-62.

Daya C.L., Vaghasiya H.U. A review on Balanites aegyptiaca Del (desert date): phytochemical constituents, traditional uses and pharmacological activity. Pharmacogn Rev.2011; 5: 55-62.

Elfeed A.A., Warrag E.I. Variation in morphological and chemical characteristics of fruits and seeds among eleven geographical sources of Balanites aegyptiaca (L) Delile in Sudan. Agric. J.N. Am. 2010; 1: 170-174.

Eze V.C., Ananso J.D. Assessment of water purification potential of Moringa oleifera seeds. International Journal of Microbiology and Application. 2014; 1: 23-30.

Fawell J., Nieuwenhuijsen M. Contaminants in drinking water. Br Med J. 2003; 68: 199-208. doi: 10.1093/bmb/Idg027

Frenzen P.D., Drake A., Angulo F. The emerging infections program foodnet working group: economic cost of illness due to Escherichia coli $\mathrm{O} 157$ infections in the United State. J Food Prot.2005; 68: 2623-2630.

Gupta S.C., Shenoy S., Kotecha M. Pharmacognostical and phytochemical evaluation of Balanites aegyptiaca Linn. Delile. Stem bark. Int. Res. J. Pharm. 2012; 3: 169-173.

Idowu A.O., Oluremi B.B., Odubao K.M. Bacteriological analysis of well water samples in Sagamu. Afr. J. Clin. Exper. Microbiol. 2011; 12: 86-91

Kalimuthu K., Prabakaram R., Sasikala T. Phytochemical screening and antioxidant activity of Boucerosia truncato-coronata (SEDGW) Gravely mayur. Int. Res. J. Pharm. 2014; 5: 663-666.

Karwautz C., Lueders T. Impact of hydraulic well restoration on native bacterial communities in drinking water wells. Microbes Environ. 2014; 29: 363-369. doi: 10.1264/jsme2.ME 14035

Khan M.A., Qureshi A.R., Uilah F., Gilani S.A., Nosheen A., Sahreen S., Laghari M.K., Laghari M.Y., Rehman S.U., Hussain U., Murad W. Phytochemical analysis of selected medicinal plants of Margalla hills and surroundings. Journal of Medicinal Plants Research. 2011; 5: 6017-6023. doi: 10.5897/JMPR11.869.

Khan M.A., Qureshi A.R., Uilah, F., Gilani S.A., Nosheen A., Sahreen S., Laghari M.K., Laghari M.Y., Rehman S.U., Hussain U., Murad W. Phytochemical analysis of selected medicinal plants of Margalla hills and surroundings. Journal of Medicinal Plants Research. 2011; 5: 6017-6023. doi: 10.5897/JMPR11.869.

Lawrence A.R., Macdonald D.M.J., Howard A.G., Pedley S.B., Ahmed K.M., Nalubega M. Guidelines for assessing the risk to groundwater from on-site sanitation. British geological survey commissioned report. 2001; CR 01(01) 142, 97 pp.

Malik A., Ahmad M. Seasonal variation in bacterial flora of the wastewater and soil in the vicinity of industrial area. Environ Monit. Assess. 2002; 73: 263-273.

National Committee for Clinical Laboratory Standards, Reference method for broth dilution antifungal susceptibility testing of yeasts. Approved standard M27-A2, 2002a; National Committee for Clinical Laboratory Standards (NCCLS); Methods for dilution antimicrobial susceptibility tests for bacteria that grow aerobically. Approved standard; document M7-A5, 5th ed., 2002b, Wayne, PA.
NF EN ISO 6222. Qualité de l'eau - Dénombrement des microorganismes revivifiables / comptage des colonies par ensemensement dans un milieu de culture nutritif gélosé ; Juillet 1999.

Nkansah M.A., Boadi N.O., Badu M. Assessment of the quality of water from hand-dug wells in Ghana. Environmental Health Insights. 2010; 4: 7-12.

Rajendran R., Balachandar S., Sudha S. Natural coagulants-An alternative to conventional methods of water purification. International Journal of Pharmaceutical Research and Bio-Science. 2013; 2: 306-314.

Sathish S.P., Amuthan A. Effect of soaking of Phyllanthus emblica wood in drinking-water for purification. Int J. Pharmacol and Clin Sci. 2012; 1: 19 - 23.

Soetan K.O. Pharmaceutical and other beneficial effects of antinutritional factors in plants. A review. Afr. J. Biotechnol. 2008; 7 : 4713-4721.

Somani S.B., Ingle N.W., Kulkarni N.S. Study of different herbs for antibacterial activity in water purification. Journal of Engineering Research and Studies. 2011; 2: 31-34.

Tula Y.M., Danchal B.T., Iruolaje O.F., Onyeje A.O.Studies on phytochemical constituents and antibacterial potentials of extracts of Balanites aegyptiaca (Del.): Parts on antibiotic resistant bacterial isolates. European Journal of Medicinal Plants, 2014; 4: 854-864.

Wadhwa, S., Panwar S.M., Saini N., Rawat S., Singhal S. A review on commercial, traditional uses, phytoconstituents and pharmacological activity of Moringa oleifera. Global J. Trad. Med. 2013; 2: $1-13$.

Wagner H. Search for new plant constituent with potential antiphlogistic and antiallergic activity. Planta Medica. 1989; 55: 235-241.

WHO. Guidelines for drinking-water quality (electronic resource): incorporating the $1^{\text {st }}$ and $2^{\text {nd }}$ addenda. 2008, Vol 1 , recommandations, $3^{\text {rd }}$ ed.

Yadav J.P., Panghal M. Balanites aegyptiaca (L.) Del. (Hingot): A review of its traditionnal uses, phytochemistry and pharmacological properties. Int. J. Green Pharm. 2010; 4: 140-146.

\section{How to cite this article:}

Kokou Anani, Yao Adjrah, Yaovi Améyapoh, Simplice Damintoti Karou, Amegnona Agbonon, Comlan de Souza, Messanvi Gbeassor. Antimicrobial activities of Balanites aegyptiaca (L.) Delile (Balanitaceae) on bacteria isolated from water well. J App Pharm Sci, 2015; 5 (10): 052-058. 